\title{
Quan-Hoang Vuong
}

Subjects: Education \& Educational Research | Archaeology

Contributor: Minh-Hoang Nguyen

social sciences interdisciplinary research philosophy of science

\section{Basic Information}

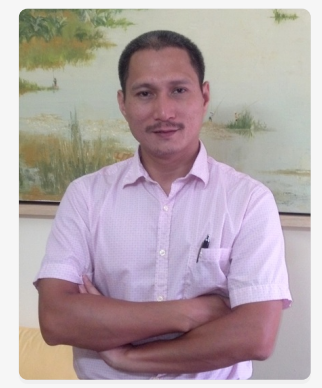

Name:

Quan-Hoang

Vuong

Birth Location: Hanoi

Titles: Scientist

Philosopher
Born:

Feb, 1972

Affiliations: Centre for Interdisciplinary Social Research, Phenikaa University Centre Emile Bernheim de Recherche Interdisciplinaire en Gestion, Université Libre de Bruxel

Vietnam Institute for Advanced Study in Mathematics

Honors: Founder of Centre for Interdisciplinary Social Research

Founder of Vietnam Chapter of the European Association of

Science Editors

World's top $2 \%$ scientist

Distinguished scientist (Phenikaa University, 2020)

Recipient of Vietnam National Journalism Prize 2010

Recipient of Vietnam National Books Prize 2007

\section{Career}

Dr. Vuong Quan Hoang (who will be identified as "Vuong" throughout this biography piece) is one of the most important figures in contemporary Vietnamese social sciences and humanities, especially after 2000. In the early 2000s, his publications focused on applied econometrics and probability, with some examples being $\left.{ }^{[1}\right][\underline{2}][\underline{3}][\underline{4}]$. Study ${ }^{[\underline{1}]}$ was the first academic paper to report anomalies and herd behavior in Vietnam's newborn stock market, just four years after its inception, and ${ }^{[\underline{3}]}$ has for more than a decade now become a key reference for practitioners and academic research in assessing and building credit risk evaluation models for Vietnamese banks' individual and corporate customers.

Vuong is currently the director of Centre for Interdisciplinary Social Research (Phenikaa University, Hanoi, Vietnam) and the Founding Chair of Vietnam Chapter of the European Association of Science Editors. Besides, he is also affiliated with the Centre Emile Bernheim de Recherche Interdisciplinaire en Gestion (CEBRIG, Université Libre de Bruxelles), in which he obtained the PhD degree in 2004. He serves as a Distinguished Associate Member with Vietnam Institute for Advanced Study in Mathematics (VIASM) during 2021-2024. His other notable positions include:

- Member of five journals' editorial boards: Humanities \& Social Sciences Communications (formerly, Palgrave Communications of Nature), Scientific Data (Nature Publishing Group), Springer Nature Social Sciences (Springer Nature), Lournal of Risk and Financial Management (MDPI), and European Science Editing (European Association of Science Editors).

- Member of Scientific Council on Basic Research in the Social Sciences and Humanities 
(Economics Section), the National Foundation for Science and Technology Development (NAFOSTED), Vietnam Ministry of Science and Technology (from 2018 to present).

- Member of the Scientific Committee of Phenikaa University (from 2019 to present).

- Member of the Hanoi Stock Exchange (HNX) Index Committee (from 2012 to 2016).

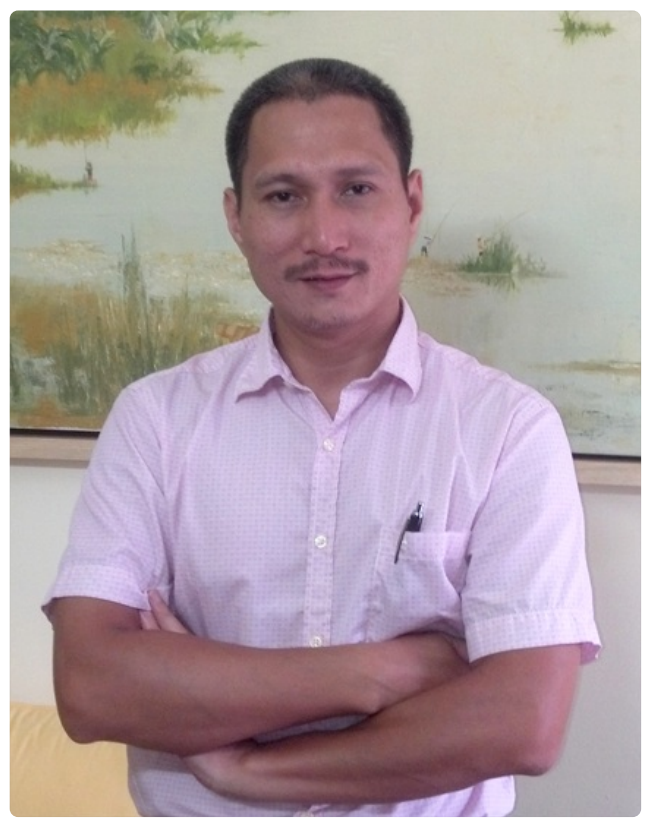

\section{2. Projects and Awards}

Since 1997, Vuong has contributed to hundreds of works and projects. His most remarkable projects and awards can be listed as follows:

- In 2009, he co-authored with Prof. Pham Minh Chính (Vietnam Prime Minister from 2021) to write a history book about Vietnamese economy. The book was titled "Kinh tế Việt Nam: Thăng trầm và đột phá" and published by the National Political Publishing House [ㄷ][6]

- In 2018, he initiated and led the SSHPA project, comprising the first Vietnamese national database on social sciences and humanities and the first Vietnamese science communication website $^{[7]}$. The project was funded by NAFOSTED during 2018-2021.

- In 2019, he collaborated with Professor Ngô Bảo Châu (Fields Medalist - Leader of VIASM \& Math Professor at University of Chicago) to start the SciMath project - the first national database of Vietnam mathematics. The database records the 80-year development of Vietnam mathematical research []ㅛㅇ][1]0]. Since 2021, he has been invited to be a Distinguished Associate Member with VIASM to continue developing the database.

- From 2017 to 2022, he has had 15 pieces of research and opinions published in Nature journals

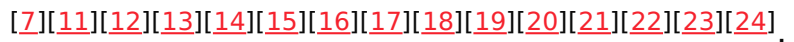

- Based on his genuine contemplation of humanistic values and wisdom in life, he wrote a collection of short stories that is titled "Ngu ngôn bói cá" [The Kingfisher story collection].

- In 2017, he collaborated with Mr. La Viet-Phuong to develop the bayesvl R package - an open Bayesian modeling and analysis software package. They officially published the software in The Comprehensive R Archive Network (CRAN) on 18 ${ }^{\text {th }}$ May 2019 [25][26][27]]. The package was introduced in various news outlets.

- He is awarded the Distinguished Scientist title by Phenikaa University (ranked first in Vietnam according to Nature Index 2021).

- He has received multiple Research Excellence Awards from affiliated universities: Phenikaa University (2018-2020), Thanh Tay University (2017), and FPT University (2016-2017).

- He was the recipient of the Vietnam National Journalism Prize 2010 and Vietnam National Books Prize 2007. 
Since 1997, Vuong has contributed to more than 180 academic publications that were published by 88 journals of various publishers in multiple disciplines. To mention a few, BMC, Brill, Cell Press, De Gruyter, Dove Press, Elsevier, Emerald, Inderscience, MDPI, MIT Press, The National Bureau of Asian Research, Nature, Oxford University Press, Palgrave Macmillan, Praeger, Springer, Taylor \& Francis, University of Warwick Press, Wiley, World Scientific, etc. Among his publications, there are 12 works published by Nature outlets: Nature, Humanities and Social Sciences Communications, Nature Human Behaviour, Scientific Data, etc.

Apart from scientific articles, he has also edited and co-edited 15 books about different issues,

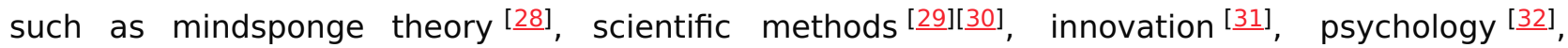

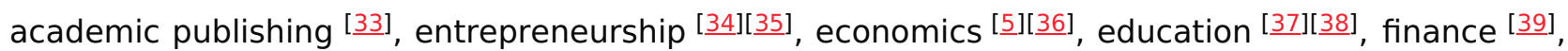

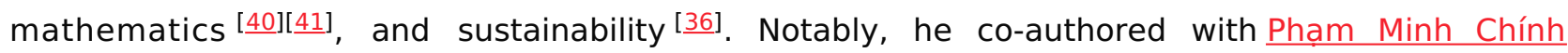
(Vietnam Prime Minister from 2021) to write a history book about the Vietnamese economy. His books are held by many libraries in the United States (US), United Kingdom (UK), France, Germany, Netherlands, Sweden, Canada, Norway, Japan, China, Vietnam, etc. To mention a few, US Library of Congress, Yale University Library, Cornell University Library, Harvard University Harvard-Yenching Library, National Library of Australia, The British Library, Temple University Libraries, Flinders University Library, Staatsbibliothek Zu Berlin - Preussischer Kulturbesitz Berlin State Library, UC Berkeley Libraries, Arizona State University Library, etc.

He has also contributed to science under the roles of an editor and reviewer. As an editor, he has provided editorial services to 85 manuscripts for journals indexed by Web of Science (WoS). As a reviewer, he has completed more than 200 peer-review reports for 75 academic journals. He was awarded Top reviewers in Cross-Field in 2018 and 2019.

His analyses and opinions have been communicated in both international (e.g. AFP, AseanAffairs, ETF Trend, Forbes, La Reppublica, Los Angeles Times, New York Times, Roubini Global Economics, Stratfor, Sina.com, VOA, Wall Street Journal, etc.) and Vietnamese media (Khoa học \& Phát triển, Kinh tế và Dự báo, Nhân Dân, Saigon Economic Times, Tiền Phong, Thanh Niên, Tuổi Trẻ, Vietnam Economic Times, VietnamNet, etc.).

\section{Contribution to Open Science}

Vuong's scientific endeavors follow his philosophy of open science in three major aspects: the cost of doing science $[\underline{13}]$, disciplined and proactive attitude $[\underline{16}]$, and transparency $[\underline{20]}$. These philosophies are deeply intertwined in his thoughts and can be observed through his main projects and proposals.

Science is facing some obstacles, such as the reproducibility crisis, costly publishing system, scientific misconducts, etc.[42][43][444][45][46][47]] . These problems, in turn, urge for changes (albeit gradually) toward open science, which can help verify claimed results, data quality, and methodological validity. In addition to open data, an open review process and open community dialogue (codes and other technical aspects) are also beneficial ${ }^{[12]}$. Therefore, every step of publishing should be transparent, including retraction - as Vuong advocates for comprehensive and open retraction notices from editors, self-retraction "heroic act" from authors, as well as an

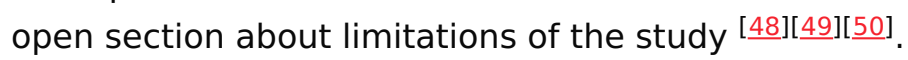

Furthermore, he and his colleague also propose the right to refuse unwanted citations for the sake of integrity [1ㅣ][리. Vuong suggests that preprints should be appreciated more for their usefulness, the preservation of original thinking, and last but not least - for being a very fast and economical publishing process [53][54] .

Against the inappropriate old ways of thinking and ethics violations in academia [55], Vuong stated 
that it requires a disciplined and proactive attitude to overcome systematic risks [리 $[\underline{16}]$. Following his philosophy, Vuong and his team published the first open Vietnamese social sciences and humanities database in Scientific Data []. He and his team also made the bayesvl - an open Bayesian analysis R package - and published the open accessed usage protocols afterwards [2ㄷ].

\section{| 5. Theoretical Frameworks and Concepts}

Since his first publication in 1997, Vuong has proposed five notable theoretical frameworks and concepts:

1. Serendipity as a strategic advantage $[\underline{56}]$

2. $3 D$ information process of creativity [ㅍ]

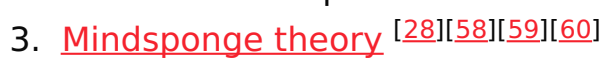

4. Cultural additivity [1ㄷ] $[\underline{61}]$

5. Semi-conducting principle [62][63]

6. Nature, emergence, and mechanism of serendipity [3]][64]

These frameworks and concepts have helped advance scientific knowledge and understanding in various research fields, with many applications across business and management, environmental conservation, psychology and public health, socio-cultural studies, etc. 


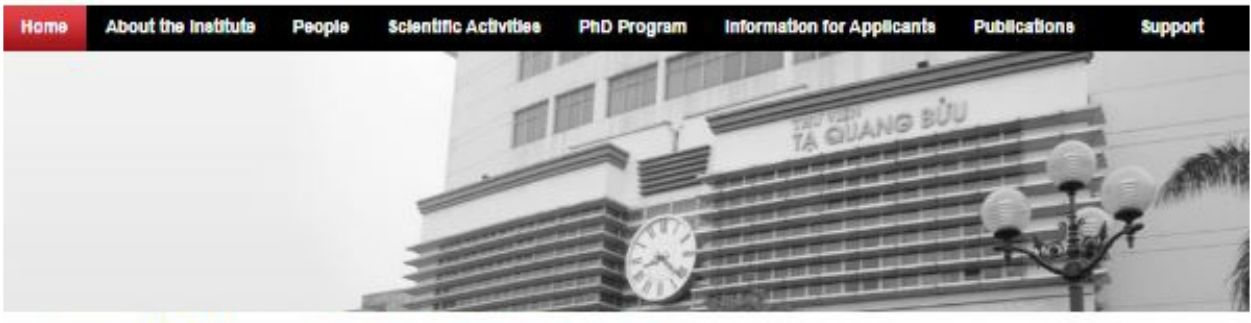

\begin{tabular}{|c|}
\hline : LONG TERM MEMBER \\
\hline Board of Derectore \\
\hline R9e日erch Fellows/ Viltore \\
\hline Internation Advlaory Board \\
\hline scientifle Councll \\
\hline staff \\
\hline $\begin{array}{l}\text { Distingulahed Asaoclate } \\
\text { Mamber }\end{array}$ \\
\hline
\end{tabular}

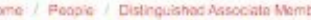
Distinguished Associate Member
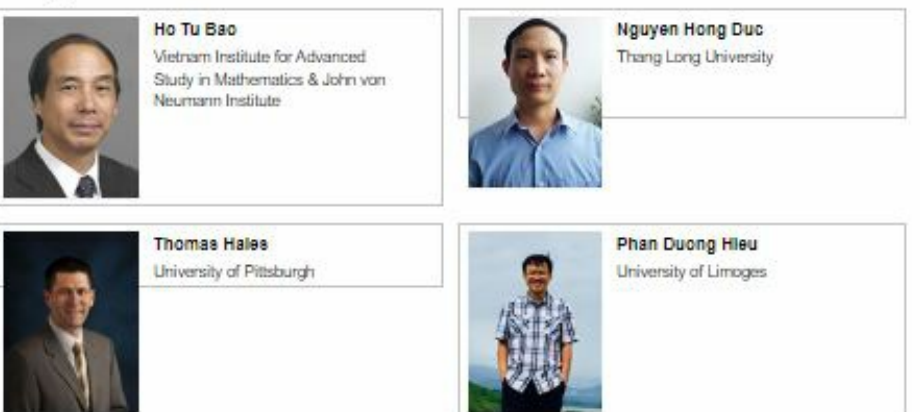

Thomas Hal9s

Universily of Pinthourgt

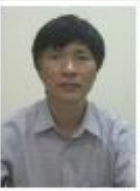

\section{Le Tuan Hos}

knstade of Matherrixics, Vecharn

Acadanny of Sciance an
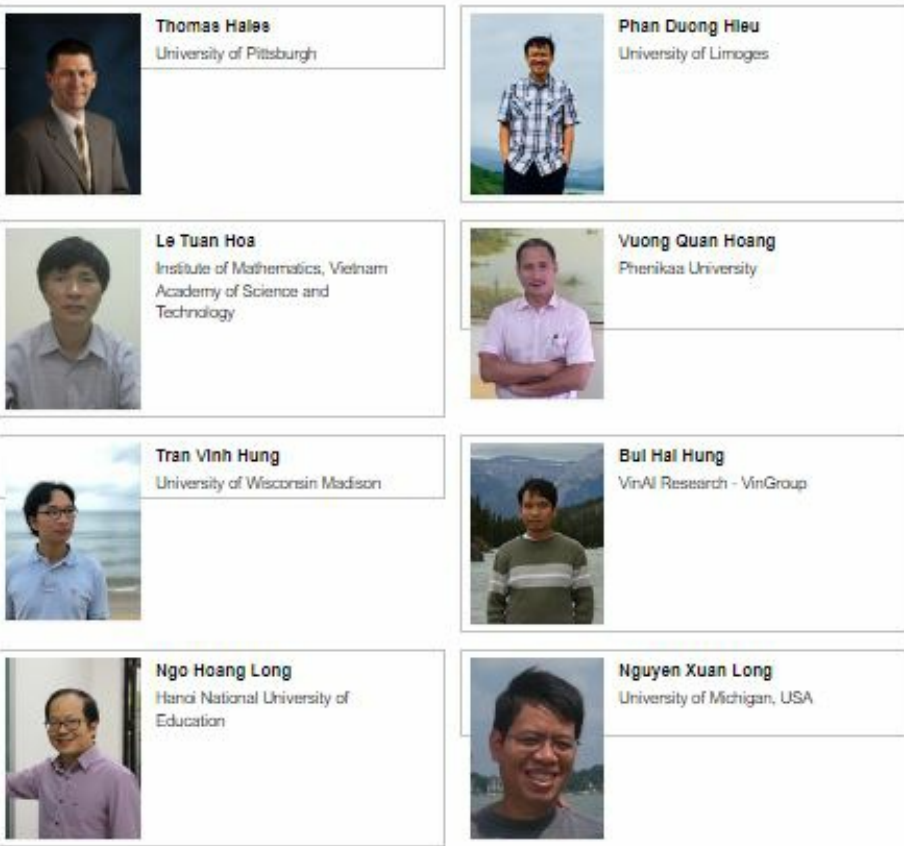

Ngo Hoang Long

Handi Naficral University of

Education

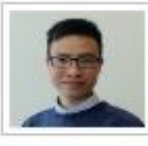

Phan Thanh Nam

Man Thanh Nam

Munith, Gantrany
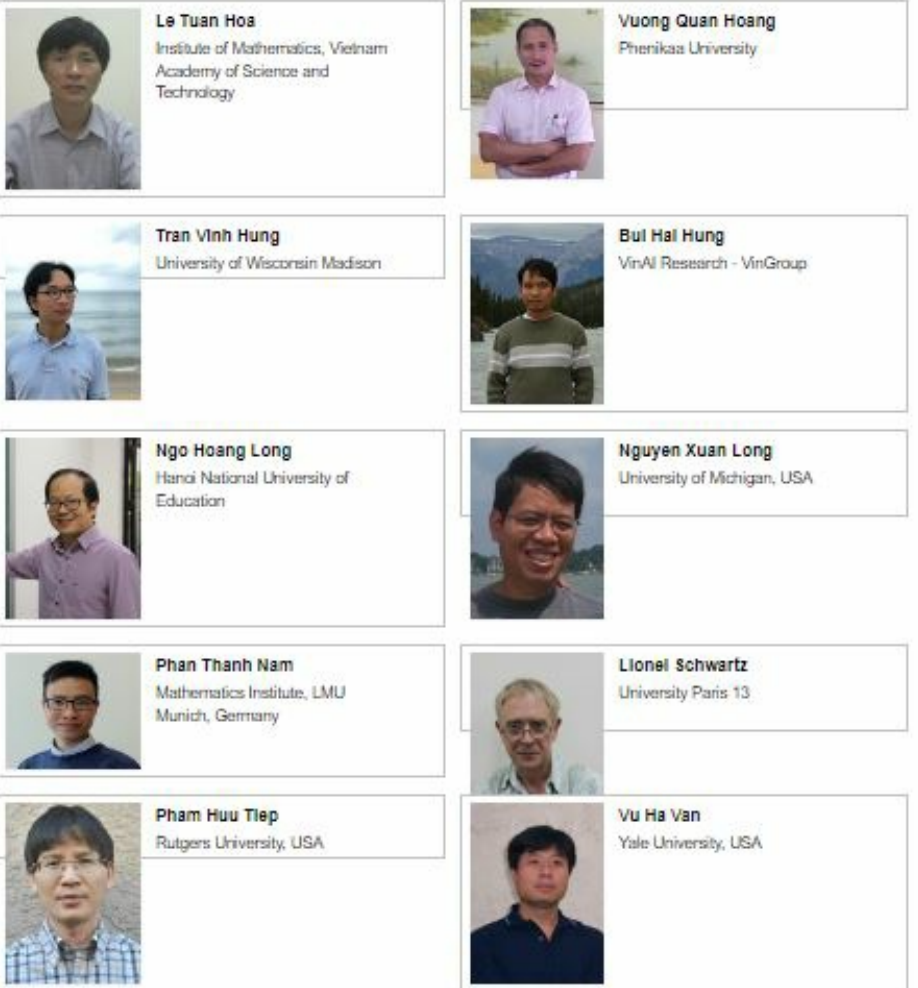

Bul Hal Hung

VinAV Research - VinGrous

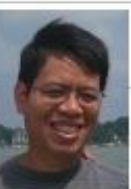

Nguyen Xuan Long

University of Mctigan, USA
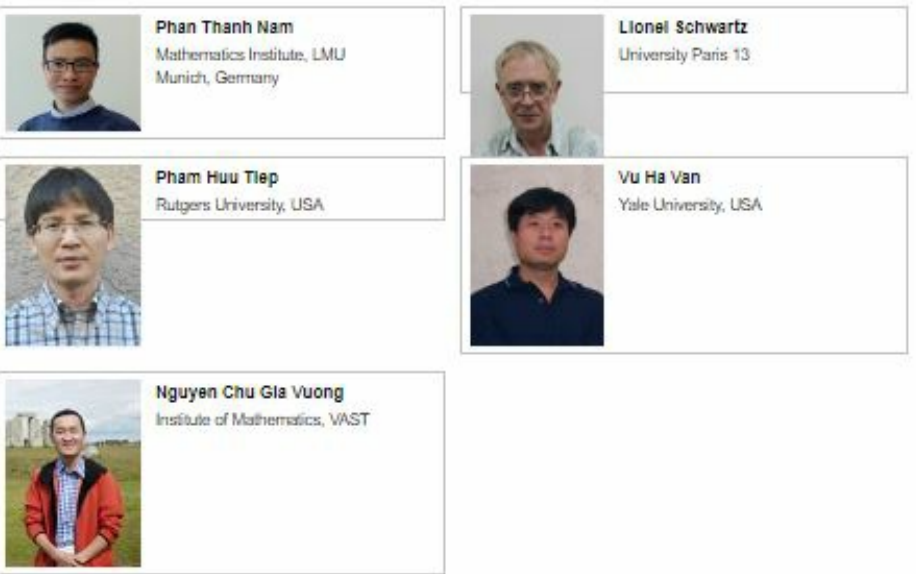

\section{| Further Reading}

https://books.google.com.vn/books?id=OSiGEAAAQBAJ\&redir esc $=y$

https://sciendo.com/book/9788367405119

https://sciendo.com/book/9788366675865

https://sciendo.com/book/9788366675599

https://mindsponge.info/about 


\section{References}

1. Farber A, Vuong QH. (2004). New empirical results on anomalies and herd behavior: Vietnam sto ck market 2000-2004. Economic Studies, 44(9), 55-59

2. Nguyen VH, Vuong QH, Tran MN. (2005). Central limit theorem for functional of jump Markov pro cesses. Vietnam Journal of Mathematics, 33(4), 443-461.

3. Hoàng VQ, et al. (2006). Phương pháp thống kê xây dựng mô hình định mức tín nhiệm khách hà ng thể nhân. Vietnam Journal of Mathematical Applications, 4(2), 1-16.

4. Nguyen VH, Vuong QH. (2007). On the martingale representation theorem and on approximate hedging a contingent claim in the minimum deviation square criterion. In: Some Topics in Indust rial and Applied Mathematics (pp. 134-151). Singapore: World Scientific.

5. Chính PM, Hoàng VQ. (2009). Kinh tế Việt Nam: Thăng trầm và đột phá. Nxb Chính trị Quốc gia, Hà Nội.

6. Le TT. (2021). ベトナム新首相と新時代のチャレンジ. OSF Preprints. https://doi.org/10.31219/osf.io/rtpf5

7. Vuong QH, La VP, Vuong TT, Ho MT, Nguyen THK, Nguyen VH, Pham HH, Ho MT. (2018). An open database of productivity in Vietnam's social sciences and humanities for public use. Scientific $D$ ata, 5, 180188. Retrieved from: https://www.nature.com/articles/sdata2018188

8. Ngo BC, Vuong QH, La VP, Le TH, Le MH, Trinh TTG, Pham HH, Nguyen TTH, Nguyen TD, Nguyen TL, Tran T, Nguyen MH, Ho MT. (2020). The 80-year development of Vietnam mathematical rese arch: Preliminary insights from the SciMath database on mathematicians, their works and their $\mathrm{n}$ etworks. arXiv. https://arxiv.org/abs/2011.09328

9. Le T, Nguyen TTH. (2021). SciMathデータベースプロジェクト : ベトナム数学の八十年間. OSF Prepri nts. https://doi.org/10.31219/osf.io/kmfwq

10. Nguyen TTH, Le TT, Dong MH. (2021). 越南统计数据库的八十年通过 Scimath 项目. OSF Preprints. https://doi.org/10.31219/osf.io/7y86n.

11. Vuong QH. (2017). Survey data on Vietnamese propensity to attend periodic general health exa minations. Scientific Data, 4, 170142. Retrieved from: https://www.nature.com/articles/sdata201 7142

12. Vuong QH. (2017). Open data, open review and open dialogue in making social sciences plausibl e. Nature: Scientific Data Updates. Retrieved from: https://go.nature.com/2QdnUrW.

13. Vuong QH. (2018). The (ir)rational consideration of the cost of science in transition economies. Nature Human Behaviour, 2(1),5. Retrieved from: https://www.nature.com/articles/s41562-017-0 281-4

14. Vuong QH, Ho MT, Nguyen THK, Vuong TT. (2018). Healthcare consumers' sensitivity to costs: a reflection on behavioural economics from an emerging market. Palgrave Communications, 4, 70 . Retrieved from:https://www.nature.com/articles/s41599-018-0127-3

15. Vuong QH, Bui QK, La VP, Vuong TT, Nguyen VH, Ho MT, Nguyen THK, Ho MT. (2018). Cultural ad ditivity: Behavioural insights from the interaction of Confucianism, Buddhism, and Taoism in folk tales. Palgrave Communications, 4,143. Retrieved from: https://www.nature.com/articles/s41599 $-018-0189-2$

16. Vuong QH. (2019). Breaking barriers in publishing demands a proactive attitude. Nature Human Behaviour, 3(10), 1034. Retrieved from: https://www.nature.com/articles/s41562-019-0667-6

17. Vuong QH, Ho MT, Nguyen THK, Nguyen MH. (2019). The trilemma of sustainable industrial gro wth: Evidence from a piloting OECD's Green city. Palgrave Communications, 5, 156. Retrieved fr om: https://www.nature.com/articles/s41599-019-0369-8

18. Vuong QH, La VP, Vuong TT, Ho MT. (2020). Earth Hour in Vietnam: a perspective from the electr 
icity industry. Nature: Behavioural \& Social Sciences. Retrieved from: https://go.nature.com/3eG zI6Y

19. Vuong QH, Nguyen THK, Ho MT, La VP, Vuong TT, Tran T, Hoang KL, Vu TH, Hoang PH, Nguyen M H, Ho MT. (2020). On how religions could accidentally incite lies and violence: Folktales as a cult ural transmitter. Palgrave Communications, 6, 82. Retrieved from: https://www.nature.com/articl es/s41599-020-0442-3

20. Vuong QH. (2020). Reform retractions to make them more transparent. Nature, 582(7811), 149. Retrieved from: https://www.nature.com/articles/d41586-020-01694-x

21. Vuong QH, Nguyen TTH, Pham TH, Ho MT, Nguyen MH. (2021). Assessing the ideological homog eneity inentrepreneurial finance research by highly cited publications. Humanities and Social Sci ences Communications, 8, 110. Retrieved from: https://www.nature.com/articles/s41599-021-00 $788-9$

22. Vuong QH, et al. (2022). Covid-19 vaccines production and societal immunization under the sere ndipity-mindsponge3D knowledge management theory and conceptual framework. Humanities and Social Sciences Communications, 9, 22. https://www.nature.com/articles/s41599-022-01034 $-6$

23. Ho MT, Mantello P, Nguyen HKT, Vuong QH. (2021). Affective computing scholarship and the rise of China: A bibliometric analysis of the period 1995-2020. Humanities and Social Sciences Com munications, 8, 282. Retrieved from: https://www.nature.com/articles/s41599-021-00959-8

24. Ho MT, Nguyen HTT, Nguyen MH, La VP, Vuong QH. (2022). Virtual Tree, Real Impact: How Simul ated Worlds Associate with the Perception of Limited Resources. Humanities and Social Sciences Communications, 9, 213. Retrieved from: https://www.nature.com/articles/s41599-022-01225-1

25. Vuong QH, La VP, Nguyen MH, Ho MT, Tran T, Ho MT. (2020). Bayesian analysis for social data: A step-by-step protocol and interpretation. MethodsX, 7, 100924. https://doi.org/10.1016/j.mex.20 20.100924

26. Vuong QH, La VP, Nguyen MH, Ho MT, Ho MT, Mantello P. (2020). Improving Bayesian statistics u nderstanding in the age of Big Data with the bayesvl R package. Software Impacts, 4, 100016. $\mathrm{h}$ ttps://doi.org/10.1016/j.simpa.2020.100016

27. La VP, Vuong QH. (2019). bayesvl: Visually learning the graphical structure of Bayesian network $s$ and performing MCMC with 'Stan'. The Comprehensive R Archive Network (CRAN). Retrieved fr om: https://cran.rstudio.com/web/packages/bayesvl/index.html

28. Vuong QH. (2022). Mindsponge Theory. AISDL. https://books.google.com/books?id=OSiGEAAAQB AJ

29. Vuong QH, Nguyen MH, La VP. (2022). The mindsponge and BMF analytics for innovative thinkin $\mathrm{g}$ in social sciences and humanities. Berlin, Germany: De Gruyter. ISBN (PDF): 978-83-67405-119; ISBN (hardcover): 978-83-67405-10-2. doi:10.2478/9788367405119

30. Hoàng VQ, Phương LV, Trung T, Hoàng NM, Toàn HM. (2021). Bản hòa tấu dữ liệu xã hội. Nxb Kho a học Xã hội, Hà Nội. ISBN: 978-604-308-549-5.

31. Vuong QH. (2022). A New Theory of Serendipity: Nature, Emergence and Mechanism. Berlin, Ger many: De Gruyter GmbH. ISBN-13: 9788366675865 . doi:10.2478/9788366675865

32. Hữu NV, Hoàng VQ. (2007) Các phương pháp toán học trong tài chính. NXB Đại học Quốc gia Hà Nội, Hà Nội: Việt Nam. http://books.google.com.vn/books?id=CVHkAY-PIZMC.

33. Vuong QH, Nguyen MH, Le TT. (2021). A mindsponge-based investigation into the psycho-religio us mechanism behind suicide attacks. Warsaw, Poland: De Gruyter / Sciendo. ISBN:

9788366675582

34. Vuong QH, Tran T. (2019). The Vietnamese Social Sciences at a Fork in the Road. Warsaw, Poland : De Gruyter (Edition: Sciendo). https://doi.org/10.2478/9783110686081 
35. Vuong QH. (2020). Entrepreneurial Finance at the Dawn of Industry 4.0. Basel, Switzerland: MDP I AG.https://doi.org/10.3390/books978-3-03943-598-2

36. Hoàng VQ. (2007). Văn minh làm giàu \& Nguồn gốc của cải. NXB Chính trị Quốc gia. Hà Nội: Việt Nam.http://books.google.com.vn/books?id=El4zVI36thsC

37. Chiến $B N$, Hoàng VQ. (2015). Bằng chứng cuộc sống: suy ngẫm về phát triển bền vững Việt $\mathrm{Na}$ m. NXB Chính trị Quốc gia, Hà Nội: Việt Nam.

38. Nancy KN, Vuong QH. (2013). What we see, why we worry, why we hope: Vietnam going forward . Boise, ID: Boise State University CCI Press.

39. Vuong QH, Vinh LA, Tran T. (2021). Academic Contributions to the UNESCO 2019 Forum on Educ ation for Sustainable Development and Global Citizenship. MDPI AG, Basel. https://doi.org/10.33 90/books978-3-0365-0681-4

40. Vuong QH. (2010). Financial Markets in Vietnam's Transition Economy: Facts, Insights, Implicatio ns. VDM-Verlag, 66123 Saarbrücken, Germany

41. Hoàng VQ, Chí NP. (2000). Nguyên lý tài chính-toán của thị trường chứng khoán. NXB Chính trị q uốc gia, Hà Nội: Việt Nam. https://books.google.com.vn/books?id=t-V6HpkdUTMC

42. Van Noorden R. (2013). Open access: The true cost of science publishing. Nature, 495(7442), 42 6-429.https://doi.org/10.1038/495426a

43. Vuong QH. (2020). Plan S, self-publishing, and addressing unreasonable risks of society publishing. LearnedPublishing, 33(1), 64-68. https://doi.org/10.1002/leap.1274

44. Munafò M. (2016). Open science and research reproducibility. ecancermedicalscience, 10.https://doi.org/10.3332/ecancer.2016.ed56

45. Open Science Collaboration. (2015). Estimating the reproducibility of psychological science. Scie nce, 349, 6251. https://doi.org/10.1126/science.aac4716

46. Fidler F, Wilcox J. (2018). Reproducibility of scientific results. The Stanford Encyclopedia of Philosophy. Retrieved from: https://plato.stanford.edu/entries/scientific-reproducibility/

47. 胡孟全, 同明玄. (2021). 研究领域执着的执着. OSF Preprints. doi: osf.io/b7mqt.

48. Teixeira da Silva JA, Vuong QH. (2021) Fortification of retraction notices to improve their transpa rency and usefulness. Learned Publishing, Early view. https://doi.org/10.1002/leap.1409

49. Vuong QH, La VP, Ho MT, Vuong TT, Ho MT. (2020). Characteristics of retracted articles based on retraction data from online sources through February 2019. Science Editing, 7(1), 34-44. https:// doi.org/10.6087/kcse.187

50. Vuong QH. (2020). The limitations of retraction notices and the heroic acts of authors who corre ct the scholarly record: An analysis of retractions of papers published from 1975 to 2019. Learn ed Publishing, 33(2), 119-130. https://doi.org/10.1002/leap.1282

51. Teixeira da Silva JA, Vuong QH. (2021). The right to refuse unwanted citations: rethinking the cul ture of science around the citation. Scientometrics, 126, 5355-5360. https://doi.org/10.1007/s11 192-021-03960-9

52. Le TT. (2021). 引用されることを拒否する権. OSF Preprints. https://doi.org/10.31219/osf.io/qxztm

53. Vuong QH. (2018). Do not underestimate the value of preprints in the social sciences and huma nities just because they are un-peer-reviewed. SSRN Electronic Journal.

http://dx.doi.org/10.2139/ssrn.3457968

54. Vuong QH. (2020). The rise of preprints and their value in social sciences and humanities. Scien ce Editing, 7(1), 70-72. https://doi.org/10.6087/kcse.193

55. Vuong QH. (2018). "How did researchers get it so wrong?" The acute problem of plagiarism in Vi etnamese social sciences and humanities. European Science Editing, 44(3), 56-58. Retrieved fro m: http://europeanscienceediting.org.uk/articles/how-did-researchers-get-it-so-wrong-the-acute- 
problem-of-plagiarism-invietnamese-social-sciences-and-humanities/

56. Napier NK, Vuong QH. (2013). Serendipity as a strategic advantage?. In Wilkinson (ed) Strategic Management in the 21st Century (Vol. 1: The Operational Environment), pp. 175-199. Westport, CT: Praeger/ABC-Clio. https://doi.org/10.13140/2.1.3311.9523

57. Vuong QH, Napier NK. (2015). Making creativity: the value of multiple filters in the innovation pr ocess. International Journal of Transitions and Innovation Systems, 3(4), 294.

https://doi.org/10.1504/IJTIS.2014.068306

58. Vuong QH. (2016). Global mindset as the integration of emerging socio-cultural values through mindsponge processes: A transition economy perspective. In J. Kuada (Ed.), Global Mindsets: Ex ploration and Perspectives (pp. 123-140). New York: Routledge.

59. Vuong QH, Napier NK. (2015). Acculturation and global mindsponge: An emerging market persp ective. International Journal of Intercultural Relations, 49, 354-367.

https://doi.org/10.1016/j.ijintrel.2015.06.003

60. 阮明皇, 胡孟全. (2021). 关于Mindsponge*bayesvl 方法的价值研究人文和社会科学现象. OSF Preprints.d oi: $10.31219 /$ osf.io/rz462.

61. Le TT. (2021). ベトナムからの人文社会科学メイン論文三本. OSF Preprints. https://doi.org/10.31219/o sf.io/g98xw

62. Vuong QH. (2021). The semiconducting principle of monetary and environmental values exchan ge. Economics and Business Letters 10(3), 284-290. https://doi.org/10.17811/ebl.10.3.2021.284290

63. Casual Philosophy. (2022). The Top 10 Philosophy Papers Published in 2021. Mindsponge.info. Re trieved from: https://mindsponge.info/posts/52

64. The Holy Grail. (2022). Review of A New Theory of Serendipity on Online Book Club. Mindsponge .info. Retrieved from: https://mindsponge.info/posts/53

65. 阮明皇, 胡孟全. (2021). 关于Mindsponge*bayesvl 方法的价值研究人文和社会科学现象. OSF Preprints.d oi:10.31219/osf.io/rz462.

66. Le TT. (2021). ベトナムからの人文社会科学メイン論文三本. OSF Preprints. https://doi.org/10.31219/o sf.io/g98xw

67. Vuong QH. (2021). The semiconducting principle of monetary and environmental values exchan ge. Economics and Business Letters 10(3), 284-290. https://doi.org/10.17811/ebl.10.3.2021.284290

68. Casual Philosophy. (2022). The Top 10 Philosophy Papers Published in 2021. Mindsponge.info. Re trieved from: https://mindsponge.info/posts/52

69. The Holy Grail. (2022). Review of A New Theory of Serendipity on Online Book Club. Mindsponge info. Retrieved from: https://mindsponge.info/posts/53

Retrieved from https://encyclopedia.pub/entry/26803 